\title{
Cytotoxic Conjugates of Fibroblast Growth Factor 2 (FGF2) with Monomethyl Auristatin E for Effective Killing of Cells Expressing FGF Receptors
}

\author{
Mateusz Adam Krzyscik, ${ }^{\dagger}$ Malgorzata Zakrzewska, ${ }^{\dagger}$ Vigdis Sørensen, ${ }^{\S}$ Aleksandra Sokolowska-Wedzina, ${ }^{\dagger}$ \\ Michal Lobocki, ${ }^{\dagger}$ Karolina Weronika Swiderska, ${ }^{\dagger}$ Daniel Krowarsch, ${ }^{\ddagger}$ Antoni Wiedlocha, ${ }^{\|}$ \\ and Jacek Otlewski*ं†
} $\dagger$ Department of Protein Engineering and ${ }^{\ddagger}$ Department of Protein Biotechnology, Faculty of Biotechnology, University of Wroclaw,
Joliot-Curie 14a, 50-383 Wroclaw, Poland
${ }_{\S}^{\S}$ Department of Core Facilities and "Department of Molecular Cell Biology, Institute for Cancer Research, Oslo University Hospital,
Montebello, 0379 Oslo, Norway

Supporting Information

ABSTRACT: Antibody-drug conjugates (ADCs) are a new class of anticancer therapeutics that combine the selectivity of targeted treatment, ensured by monoclonal antibodies, with the potency of the cytotoxic agent. Here, we applied an analogous approach, but instead of an antibody, we used fibroblast growth factor 2 (FGF2). FGF2 is a natural ligand of fibroblast growth factor receptor 1 (FGFR1), a cell-surface receptor reported to be overexpressed in several types of tumors. We developed and characterized FGF2 conjugates containing a defined number of molecules of highly cytotoxic drug monomethyl auristatin E (MMAE). These conjugates effectively targeted FGFR1-expressing cells, were internalized upon FGFR1-mediated endocytosis, and, in consequence, revealed high cytotoxicity, which was clearly related to the FGFR1 expression level. Among the conjugates tested, the most potent was that bearing three MMAE molecules, showing that the cytotoxicity of protein-drug conjugates in vitro is directly

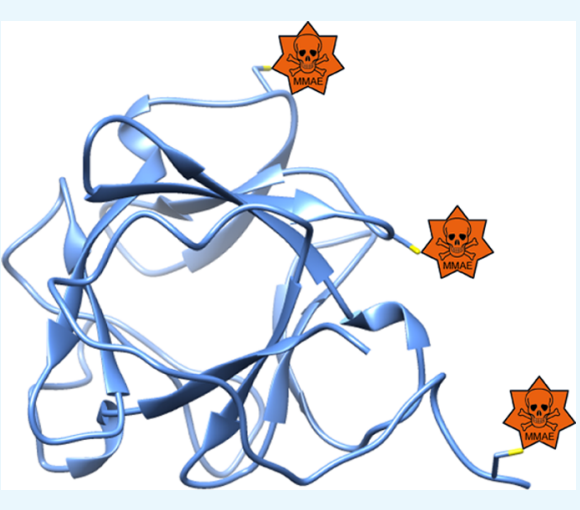
dependent on drug loading.

\section{INTRODUCTION}

More than 100 years has passed since Paul Ehrlich postulated the concept of powerful and tailored antitumor drugs termed "magic bullets", and fully effective cancer treatment is still being pursued. ${ }^{1,2}$ Currently, the most promising approach is targeted therapy, especially the one based on antibody-drug conjugates (ADCs) composed of a monoclonal antibody as the targeting molecule and a highly cytotoxic agent. ${ }^{3-5}$ A clear advantage of using antibodies is their ability to recognize virtually any molecular target, including those present on malignant cells., However, there are many other natural ligands that form complexes with specific cell-surface proteins overexpressed in cancer cells.

One such group comprises fibroblast growth factors (FGFs), which bind with high affinity to FGF receptors (FGFRs) found to be upregulated in many types of tumors, including bladder, breast, lung, rhabdomyosarcoma, and multiple myeloma., Currently, numerous studies exploit FGFRs as potential therapeutic targets. The most common approaches involve the use of small-molecule inhibitors to block the receptor tyrosine kinase activity, FGF traps, and monoclonal antibodies to eliminate ligand binding and prevent receptor activation. ${ }^{9-12}$

Recently, we showed that FGF1 could be effectively applied to deliver a cytotoxic agent (monomethyl auristatin E, MMAE) specifically to FGFR-expressing cells, working as a Trojan horse by sensitizing the cells to the cytotoxic drug action. ${ }^{13,14}$ However, FGF1 exhibits a major disadvantage as a delivery vehicle. It is inherently unstable, and, even upon the introduction of stabilizing mutations, is prone to unfolding upon covalent attachment of the hydrophobic drug molecule to its single exposed Cys117 residue. ${ }^{13}$ To overcome this limitation, we introduced Cys to Ser mutations and in parallel cysteine-containing specific sequences at the FGF1 N- or Cterminus, which allowed us to attach the cytotoxic cargo through maleimide chemistry with high yield and specificity. With this approach, however, we were able to obtain only singly substituted conjugates of FGF1. ${ }^{13,14}$ To increase the drug-toprotein ratio (DPR), here we applied another canonical member of the FGF family, fibroblast growth factor 2 (FGF2), as the FGFR-targeting molecule.

FGF2 contains four cysteines, two of which are highly exposed, offering the possibility of addition of two MMAE molecules. Because FGF2 is more resistant than FGF1 to thermal unfolding, aggregation, and proteolysis, ${ }^{15-18}$ we

Received: February 1, 2017

Accepted: June 28, 2017

Published: July 21, 2017 


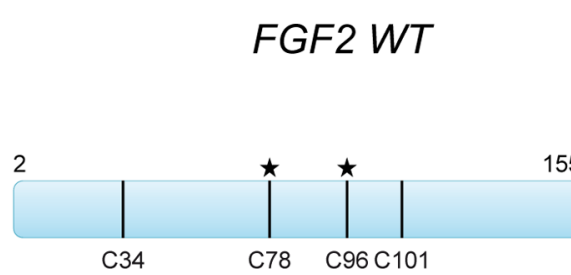

KCK-FGF2

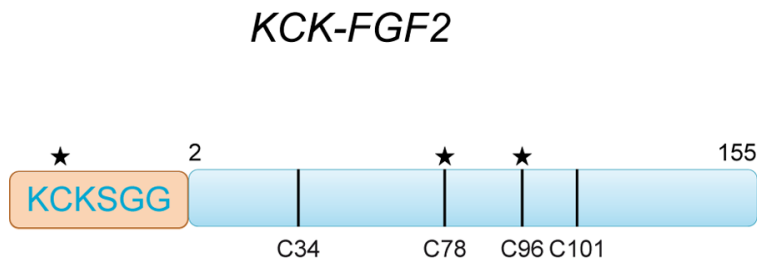

FGF2-KCK

2

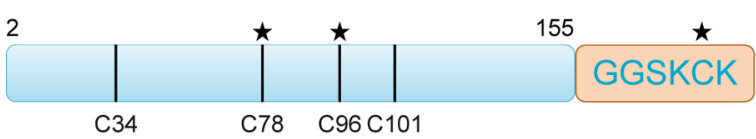

KCK-FGF2[C78S/C96S]

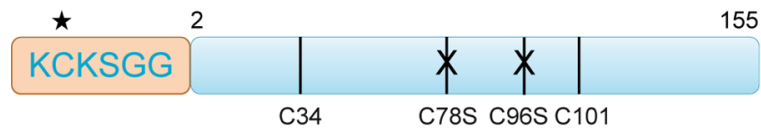

FGF2[C78S/C96S]-KCK

$$
\text { 2 }
$$
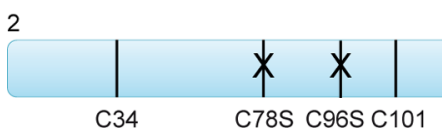

155

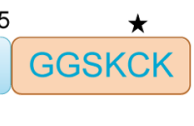

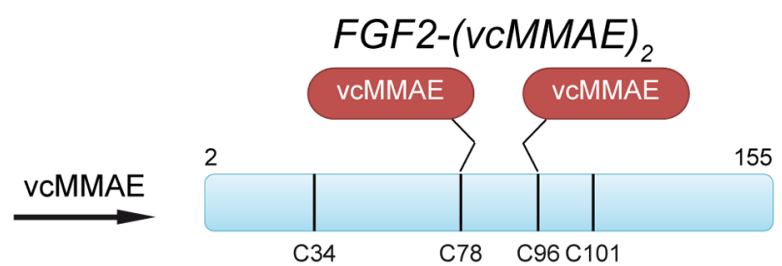

KCK-FGF2-(VCMMAE) ${ }_{3}$
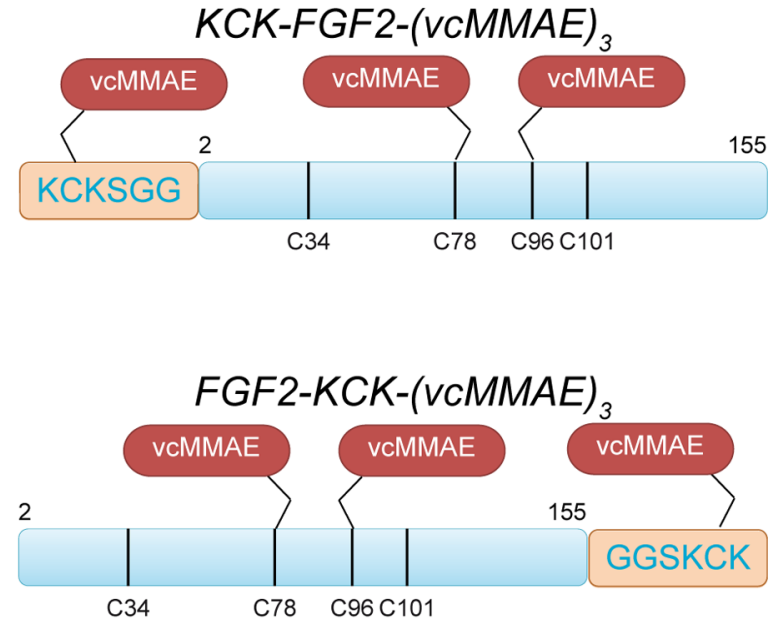

KCK-FGF2[C78S/C96S]-(vcMMAE) vcMMAE

$\stackrel{\text { vcMMAE }}{\longrightarrow}$

FGF2[C78S/C96S]-KCK-(vCMMAE), vcMMAE

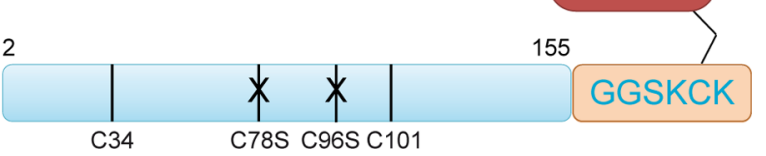

Figure 1. FGF2 constructs with conjugation sites marked. The asterisks correspond to the conjugating cysteines and X's indicate the cysteines mutated to serines.

considered that it might tolerate the MMAE molecules attached directly to its native sequence. In contrast to FGF1, which binds to all FGFRs, FGF2 exhibits higher specificity being a ligand only for FGFR1c, FGFR3c, and FGFR4. ${ }^{19,20}$ Moreover, FGF2 is effectively endocytosed through an FGFR-dependent mechanism, ${ }^{21,22}$ and efficient internalization is a key parameter in the case of delivery systems for highly cytotoxic drugs as it allows for specific release of the active form of the cytotoxic compound only inside the target cell. ${ }^{23}$

In this article, we describe the design and characterization of novel cytotoxic conjugates based on the FGF2 molecule and MMAE. These bioconjugates were effectively internalized and demonstrated a significantly higher cytotoxicity in cell lines expressing fibroblast growth factor receptor 1 (FGFR1) than in the control cell line. In our system, the stoichiometry of the conjugate (DPR) could be controlled precisely and the number of drug molecules attached correlated positively with the cytotoxic potency of the FGF2 conjugates.

\section{RESULTS}

Design and Production of FGF2 Variants. Wild-type FGF2 contains four cysteine residues, two of them (Cys34 and Cys101) are buried and inert and two (Cys78 and Cys96) are exposed and highly reactive. ${ }^{24}$ To control the number of drug molecules attached to FGF2, we constructed several variants that are shown in Figure 1. Substitution of the two surface cysteine residues with serines (Cys78Ser and Cys96Ser) combined with the introduction of the KCKSGG sequence at 


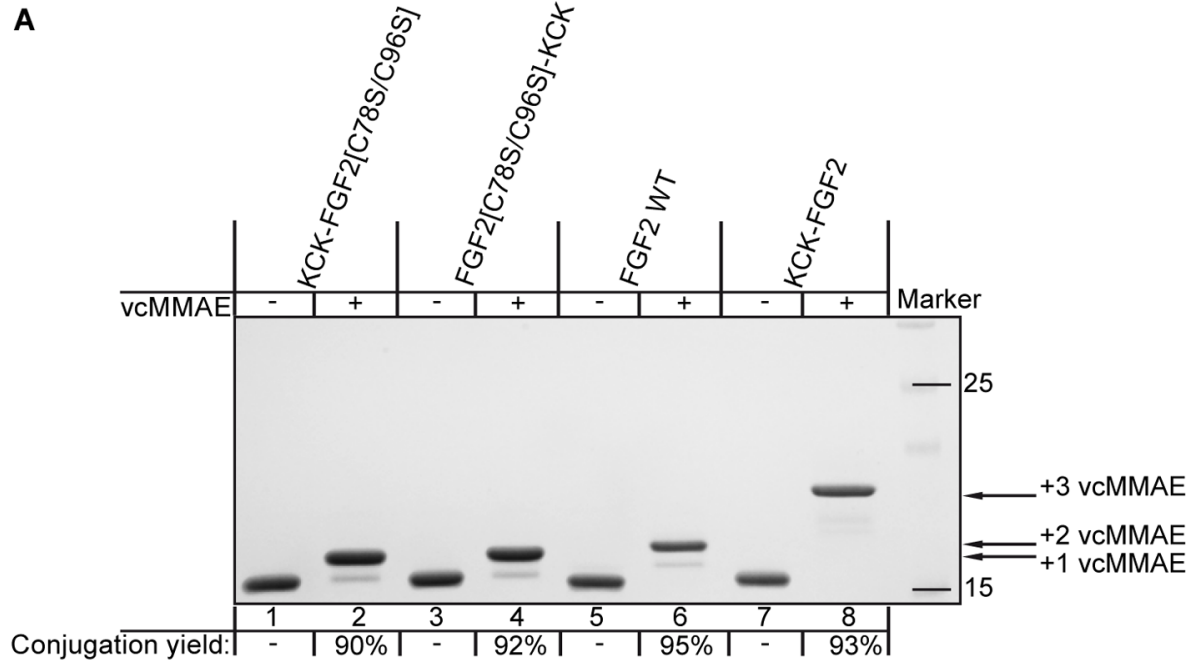

B

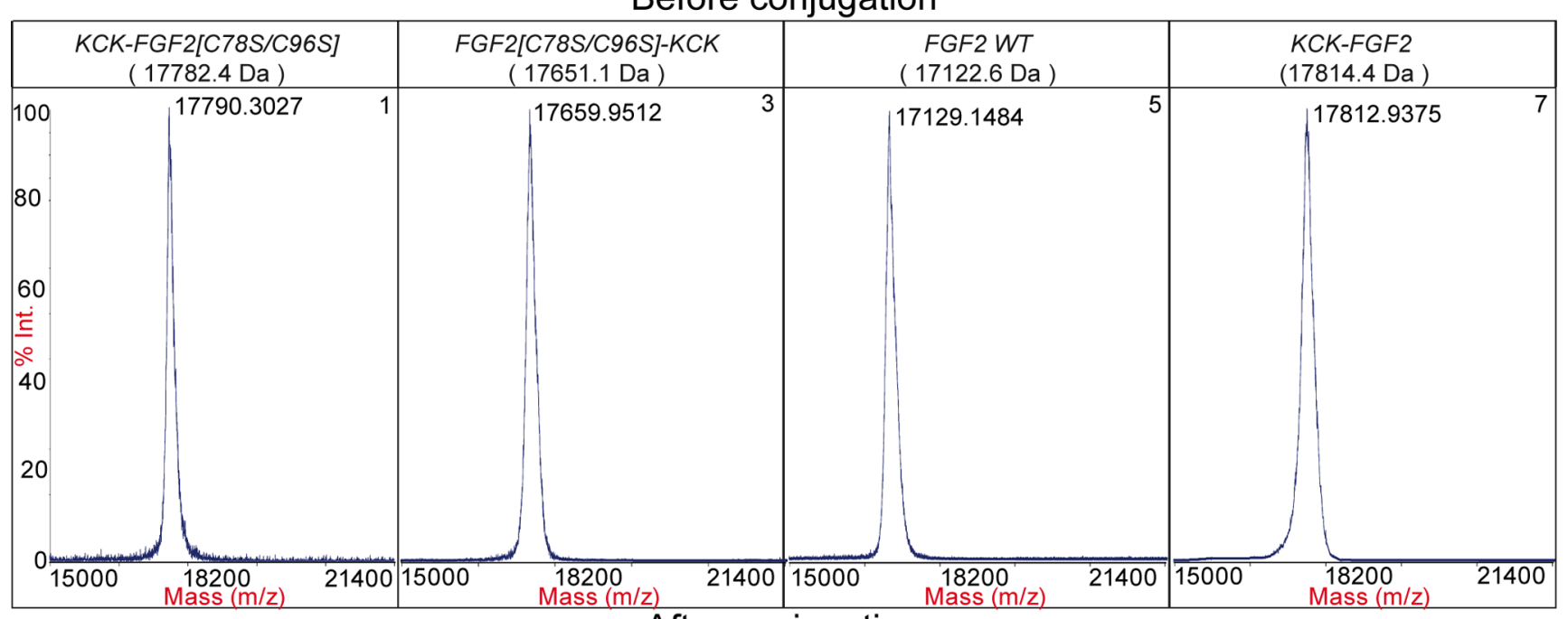

After conjugation

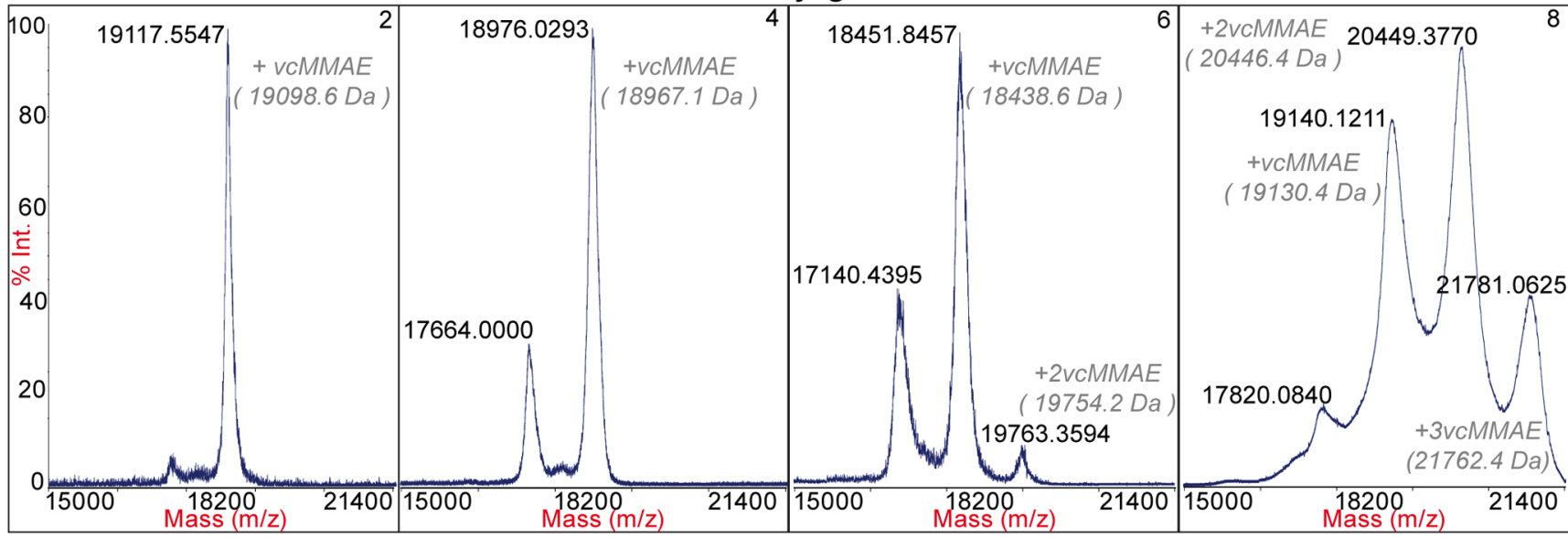

Figure 2. Conjugation of FGF2 variants with vcMMAE. (A) Electrophoretic separation with the conjugation yield calculated from HPLC analysis showed in Figure S1. (B) Mass spectra of FGF2 variants before (upper panel) and after (lower panel) the reaction performed for $1 \mathrm{~h}$ at $25^{\circ} \mathrm{C}$, as detailed in Materials and Methods. Numbers of MS data correspond to the lane numbers in (A).

the N-terminus or GGSKCK at the C-terminus (in both cases abbreviated KCK) allowed us to generate two monosubstituted FGF2 conjugates. Wild-type FGF2 with two exposed cysteines intact should give a doubly substituted conjugate. To obtain triply substituted conjugates, we used wild-type FGF2 extended with the KCK sequence on either terminus. The cysteine residue flanked with lysines is highly reactive and ensures excellent yield of the conjugation reaction. ${ }^{14}$ 

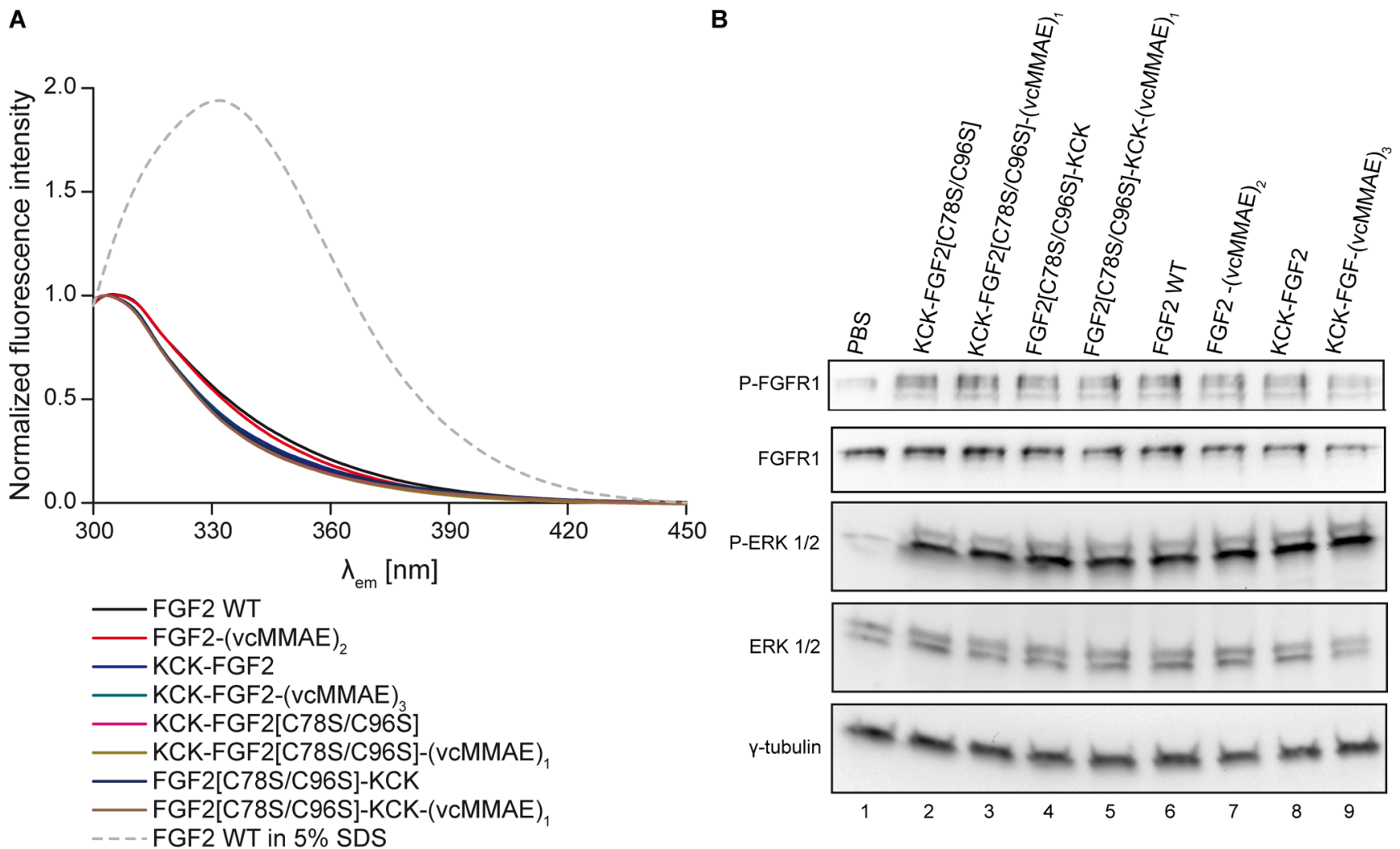

Figure 3. Functional competence of FGF2-vcMMAE conjugates. (A) Fluorescence emission spectra of FGF2 variants and their conjugates. The dashed line represents FGF2 WT unfolded by 5\% SDS. Measurements were performed at a protein concentration of $4 \times 10^{-6} \mathrm{M}$ upon excitation at $280 \mathrm{~nm}$. Curves were normalized to tyrosine emission at $303 \mathrm{~nm}$. (B) Activation of FGFR1 (phospho-FGFR1) and ERK 1/2 (phospho-p44/42 MAPK) in NIH 3T3 cells after 15 min stimulation with $100 \mathrm{ng} / \mathrm{mL}$ FGF2 variants or their conjugates in the presence of $10 \mathrm{U} / \mathrm{mL}$ heparin detected by Western blotting. Total amount of FGFR1, ERK 1/2 (p44/42 MAPK), and $\gamma$-tubulin served as loading control.

We successfully expressed and purified all FGF2 variants. The yield was between 8 and $40 \mathrm{mg} / \mathrm{L}$ of culture. All of the variants exhibited highly similar elution profiles during purification on heparin-Sepharose.

Conjugation of FGF2 Variants with MMAE. As a cytotoxic compound delivered by FGF2, we used maleimidocaproyl-Val-Cit-PABC-monomethylauristatin E (abbreviated vcMMAE), a highly cytotoxic derivative of dolastatin containing a maleimide moiety suitable for conjugation to a cysteine residue and a protease-sensitive valine-citrulline dipeptide designed for optimal stability in human plasma and effective cleavage by human cathepsin B. ${ }^{13,25}$

We optimized the conjugation reaction to provide high yield and optimal conditions, preventing protein unfolding and a loss of receptor-binding activity. Different temperatures $(4,15,25$, $37^{\circ} \mathrm{C}$ ), reaction times $(10,30 \mathrm{~min}, 1,6$, and $24 \mathrm{~h}$ ), buffer compositions, including buffering agents (phosphate, HEPES, Tris), salts $\left(\mathrm{NaCl}, \mathrm{Na}_{2} \mathrm{SO}_{4},\left(\mathrm{NH}_{4}\right)_{2} \mathrm{SO}_{4}\right.$ at a concentration range of $0-1 \mathrm{M})$, and $\mathrm{pHs}(6.5,7.0,7.5,8.0)$ were tested. Finally, for all protein variants, the conjugation was performed for $1 \mathrm{~h}$ at $25{ }^{\circ} \mathrm{C}$ in the reaction buffer containing $50 \mathrm{mM}$ monosodium phosphate, $10 \mathrm{mM} \mathrm{Na}_{2} \mathrm{SO}_{4}, 10 \mathrm{mM}$ methionine, and $1 \mathrm{mM}$ EDTA, at $\mathrm{pH}$ 7.0. When vcMMAE was added to FGF2 WT, its two exposed cysteines were substituted and the other two remained unmodified (Figures 2 and S1). Also, in all of the other FGF2 constructs, the two buried cysteines were not reactive and the expected drug molecule loading was achieved (DPR value from 1 to 3 ) (Figures 2 and S1). The conjugation gave highly homogenous preparations containing negligible amounts of the unconjugated species, as shown by sodium dodecyl sulfate-polyacrylamide gel electrophoresis (SDS-PAGE) (Figure 2a). The identity of the conjugates was confirmed by matrix-assisted laser desorption ionizationmass spectrometry (MALDI-MS) (Figure 2b). However, this technique did not allow us to withdraw unequivocal conclusion on DPR due to the fact that some vcMMAE moieties split off during the ionization/desorption process. ${ }^{26}$ The homogeneity of conjugates and their DPR were further confirmed by highperformance liquid chromatography (HPLC) quantitative analysis (Figures 2a and S1, Table S1). All but one FGF2 conjugate were soluble; the triply loaded variant with the $\mathrm{C}$ terminus extended (FGF2-KCK-(vcMMAE) ${ }_{3}$ ) precipitated in PBS and was therefore excluded from further experiments.

To verify the native conformation of the FGF2 variants before and after conjugation, we performed fluorescence analysis (Figure 3a), which is a useful indicator of proper folding of FGF2. ${ }^{27}$ The fluorescence spectrum of natively folded wild-type FGF2 shows very low emission at $353 \mathrm{~nm}$ because the signal from the single tryptophan residue is completely quenched and the spectrum is dominated by emission of tyrosine residues (maximum at $303 \mathrm{~nm}$ ). Upon unfolding (with a denaturating agent such as SDS), the quenching effect is abolished, resulting in a significant increase of fluorescence at $353 \mathrm{~nm}$ (Figure 3a). The fluorescence emission spectra of all of the proteins before and after conjugation were similar to those of native FGF2 WT, showing no changes in the tertiary structure of the variants and their conjugates with vcMMAE. 

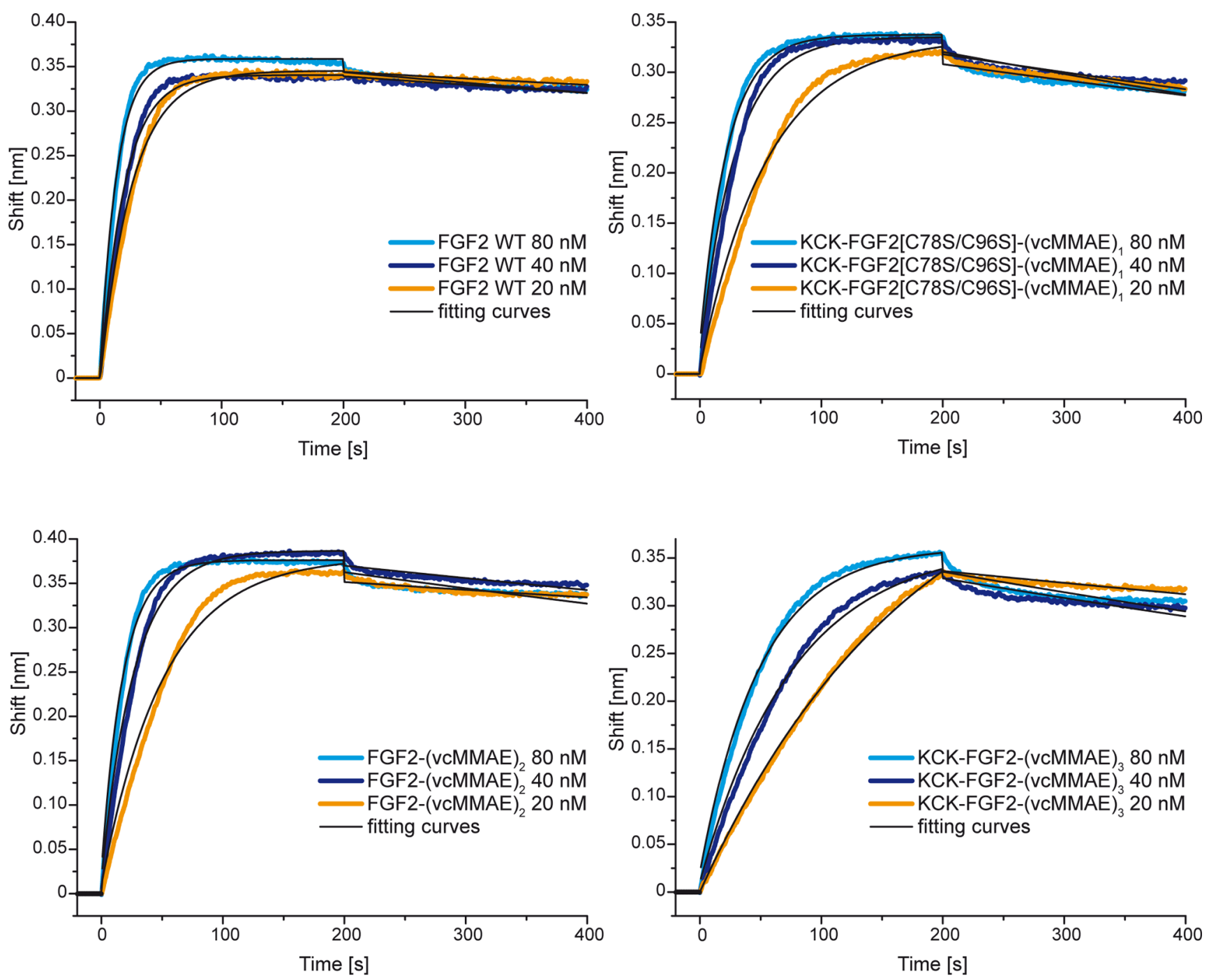

Figure 4. BLI analysis of the interaction of wild-type FGF2 or FGF2 conjugates with FGFR1c. The solid lines represent local fits to the 1:1 interaction model.

Biological Competence of FGF2 Variants and Their Conjugates. To verify if the introduced mutations (Cys to Ser substitutions and $\mathrm{N}$ - and C-terminal extensions) or vcMMAE conjugation did not affect the binding of the FGF2 derivatives to FGFRs, we analyzed activation of signaling pathways in NIH $3 \mathrm{~T} 3$ cells upon a $15 \mathrm{~min}$ treatment with the modified FGF2. All of the conjugates stimulated the downstream signaling at the same level as did FGF2 WT, as detected by Western blotting with anti-phospho-ERK $1 / 2$ antibodies and anti-phosphoFGFR1 (Figure 3b). This result indicates that the introduced modifications of FGF2 not only did not affect the protein conformation but also did not impair the short-term FGFinduced cellular response. We also analyzed the binding of selected conjugates to the recombinant extracellular part of FGFR1c using Biolayer interferometry (BLI; Figure 4, Table $1)$. This in vitro method of protein-protein interaction measurements revealed some variations (within 1 order of magnitude range) in the binding parameters of the wild-type FGF2 and FGF2 conjugates. The mean dissociation constant for wild-type FGF2 was equal to $2.43 \times 10^{-10} \mathrm{M}$, whereas for conjugates, it was in the range from $4.43 \times 10^{-10}$ to $20.8 \times$ $10^{-10} \mathrm{M}$, with the highest value for triply substituted conjugate.
Internalization of FGF2-vcMMAE Conjugates. Because the main aim of our study was the specific delivery of the cytotoxic cargo into FGFR-positive cells, we checked whether the FGF2 conjugates are able to enter the cell, using confocal microscopy. Two FGF2 conjugates, KCK-FGF2[C78S/C96S]$(\mathrm{vcMMAE})_{1}(\mathrm{DPR}=1)$ and KCK-FGF2- $(\mathrm{vcMMAE})_{3}(\mathrm{DPR}=$ 3) were labeled with fluorescent dye DyLight 550. The endocytic uptake was analyzed in U2OS cells stably expressing FGFR1 (U2OS-R1) and in untransfected cells (U2OS). The untransfected U2OS cells were prestained with CellTrace Violet and cocultured with an equal number of nonstained U2OS-R1 cells, which allowed us to discriminate between the two cell lines on the same coverslip. Both the FGF2 conjugates produced the DyLight550-specific fluorescence only in U2OS$\mathrm{R} 1$ cells (Figure 5), and their cellular distribution was very similar to that of early endosome antigen 1 (EEA1), indicating that their internalization occurs effectively in an FGFRdependent manner, similar to that of FGF2 WT.

To demonstrate the subcellular localization of the internalized FGF2 and its conjugates, we performed high-resolution microscopy. U2OS-R1 cells were incubated with FGF2 WT, KCK-FGF2[C78S/C96S]-(vcMMAE) $)_{1}$, or KCK-FGF2$(\mathrm{vcMMAE})_{3}$ at $37{ }^{\circ} \mathrm{C}$ for $40 \mathrm{~min}$ and then stained using 


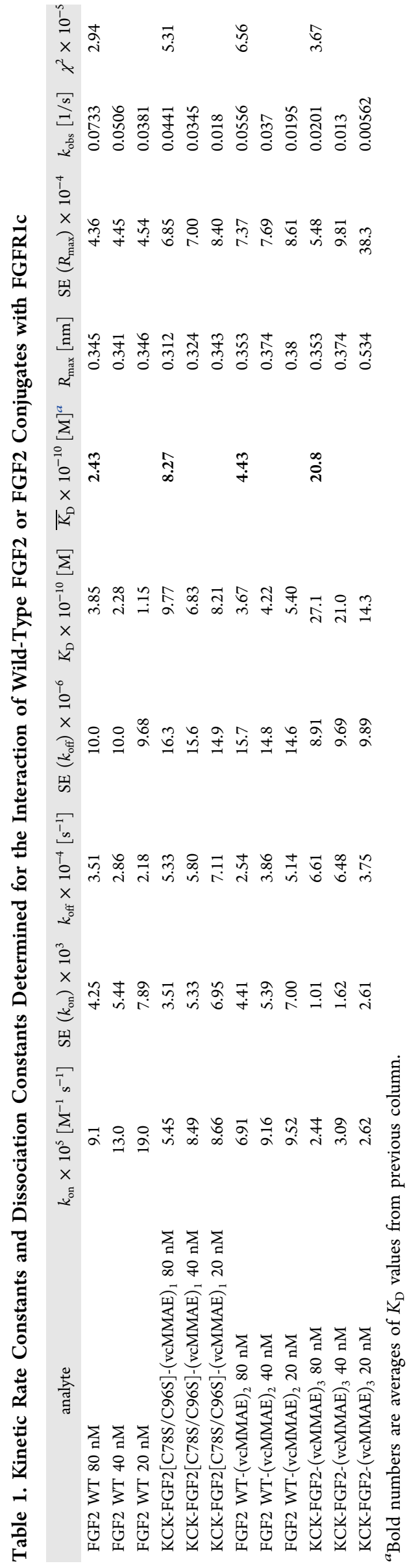

anti-FGF2, anti-FGFR1, and anti-EEA1 antibodies (Figure 6). In all three samples, FGF2 and FGFR1 were found to colocalize in intracellular vesicles, mostly those positive for EEA1, a membrane-bound marker of early endosomes. Thus, both the conjugates tested, similarly to WT FGF2, are internalized efficiently by an FGFR1-mediated mechanism via the endocytic pathway.

Because conjugates containing vcMMAE should undergo cathepsin B cleavage, which occurs predominantly in lysosomes, we also checked whether internalized FGF2vcMMAE conjugates eventually reached the lysosomal compartment. Just after $90 \mathrm{~min}$ of incubation, we observed colocalization of FGF2 conjugates with the lysosomal marker, LAMP-1 (Figure S2). These results confirm the delivery of FGF2 conjugates to lysosomes.

Cytotoxic Effect of FGF2 Conjugates. To assess the toxicity of the FGF2 conjugates, we used three cell lines differing in the FGFR1 level: BJ (nonmalignant cells naturally expressing a moderately high level of FGFR1), U2OS (cells that show a hardly detectable level of FGFR1 and serve as a negative control), and U2OS-R1 (U2OS cells stably expressing FGFR1 at a very high level).$^{13}$ For each cell line, we verified the level of total FGFR1 by Western blot analysis (Figure S3), as well as the level of FGFR1 accessible for the ligand on the cell surface by flow cytometry (Figure S4).

The cells were treated for $96 \mathrm{~h}$ with FGF2 WT or four different FGF2 conjugates in the concentration range of 0.04$4000 \mathrm{nM}$, and their viability was assessed with the Alamar Blue assay. The sensitivity toward the FGF2 conjugates differed considerably between the cell lines and correlated with the level of FGFR1 on their surface (Figure 7). Remarkably, the toxicity toward the U2OS cells was roughly 2 orders of magnitude lower than that toward the U2OS-R1 cells (Table 2). In U2OS$\mathrm{R} 1$ cells, the $\mathrm{EC}_{50}$ values were equal to 2.2 and $4.1 \mathrm{nM}$ for KCK-FGF2-(vcMMAE) ${ }_{3}$ and FGF2-(vcMMAE), respectively. As a control, we used free MMAE at $11 \mu \mathrm{M}$, which exhibited very similar toxicity in all of the cell lines tested (Figure 7).

Additionally, we observed a positive correlation between the DPR and the toxic effect of the conjugates (Figure 7 and Table 2). KCK-FGF2-(vcMMAE) ${ }_{3}$ revealed the highest cytotoxicity, whereas singly substituted conjugates (KCK-FGF2[C78S/ C96S]-(vcMMAE) $)_{1}$ and FGF2[C78S/C96S]-KCK(vcMMAE $)_{1}$ ) showed the lowest.

Taken together, our results demonstrate high specificity and potency of FGF2-vcMMAE conjugates in killing FGFR1expressing cells.

The half-maximal effective concentration $\left(\mathrm{EC}_{50}\right)$ was calculated from the concentration-response curve obtained for each mutant. Data are mean values of three independent experiments (every point in each individual experiment also being evaluated in triplicate) \pm SE.

\section{DISCUSSION}

In recent years, targeted cancer therapy is becoming a paradigm for effective cancer treatment. The most developed strategy employs antibodies that specifically recognize defined molecular markers on cancer cells. ${ }^{28-31}$ Only few cases have been reported of using naturally occurring ligands binding to proteins overexpressed on cancer cells for specific delivery of a toxic drug. One example is the application of transferrin conjugated to chemotherapeutic agents, such as adriamycin, daunorubicin, and metotrexat, or toxins, including ricin and diphtheria toxin. ${ }^{32}$ Others have proposed a specific delivery 


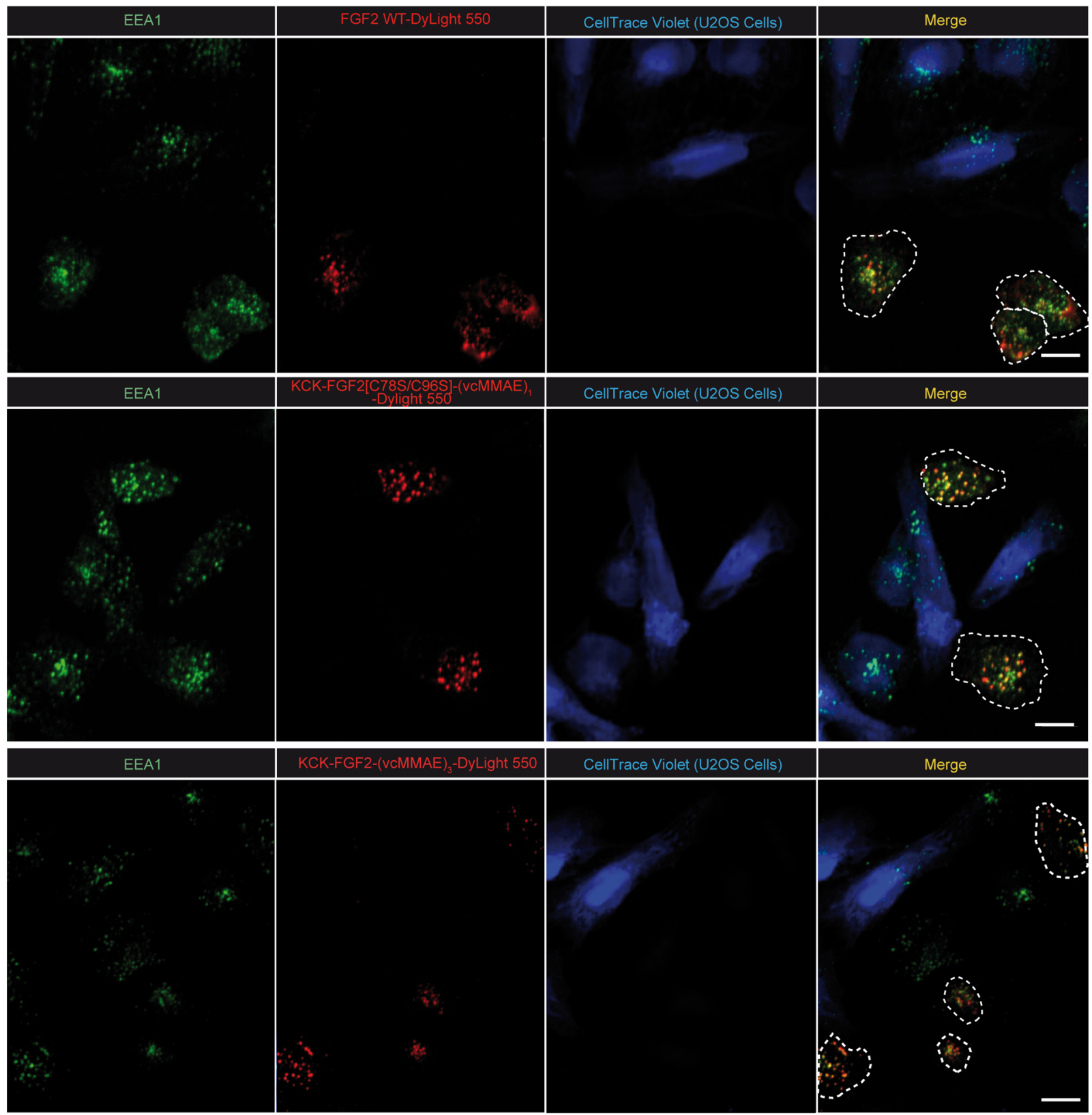

Figure 5. Specific internalization of the FGF2 WT and FGF2-vcMMAE conjugates into the cells expressing FGFR1. Shown are the representative images of internalization of FGF2 WT, KCK-FGF2[C78S/C96S]-(vcMMAE) ${ }_{1}$, or KCK-FGF2-(vcMMAE) ${ }_{3}$ into U2OS-R1 cells vs U2OS cells. Equal numbers of U2OS cells stably stained with CellTrace Violet (blue) and U2OS-R1 (nonstained) were grown together and then incubated with $1000 \mathrm{ng} / \mathrm{mL}$ FGF2 WT, KCK-FGF2[C78S/C96S]-(vcMMAE) ${ }_{1}$, or KCK-FGF2-(vcMMAE) ${ }_{3}$ labeled with DyLight550 (red) at $37{ }^{\circ} \mathrm{C}$ for $15 \mathrm{~min}$. The cells were fixed, stained with anti-EEA1 antibody (green), and examined by confocal microscopy. U2OS-R1 cells are marked with a dashed line. The bar corresponds to $10 \mu \mathrm{m}$.

strategy based on folate receptors because its expression is augmented in several types of cancer. ${ }^{33-36}$ Folic acid conjugated to doxorubicin-loaded magnetic nanospheres ${ }^{37}$ or PEG-PLGA copolymer nanoparticles containing cisplatin and paclitaxel $^{38}$ destroyed cancer cells effectively.

In this study, we employed FGF2 as the targeting molecule to deliver a cytotoxic compound, MMAE, to the cells presenting FGFR1c on their surface. This receptor plays a significant role in a wide variety of human tumors. Several types of cancer, including carcinomas, sarcomas, and glioblastomas, seem to be a consequence of FGFR1 aberrations, especially gene amplification, leading to receptor overproduction. ${ }^{39}$ FGFR1 is relatively often overexpressed in squamous cell lung cancer (up to 20\%), small-cell lung cancer (6\%), breast cancer (10\%), head and neck cancer (up to $17 \%$ ), esophageal squamous cell carcinoma (20\%), adenocarcinoma (9\%), osteosarcoma $(5 \%)$, and ovarian and bladder tumors. ${ }^{39-43}$

As a model of FGFR-dependent cancer, we used a cell line with high expression of FGFR1, U2OS cell stably transfected with FGFR1. ${ }^{44}$ To produce FGF2 conjugates, we applied wellestablished protocols for $\mathrm{ADC}$ construction, including the ValCit linker and conjugation chemistry. ${ }^{45-47}$

Only few attempts to generate conjugates of FGFs have been published to date, including a conjugate of FGF2 with PEG and adenoviral vectors, ${ }^{48}$ attachment of polymers (G5 polyamidoamine dendrimer or poly(ethylene glycol)-cholesterol polymer) 


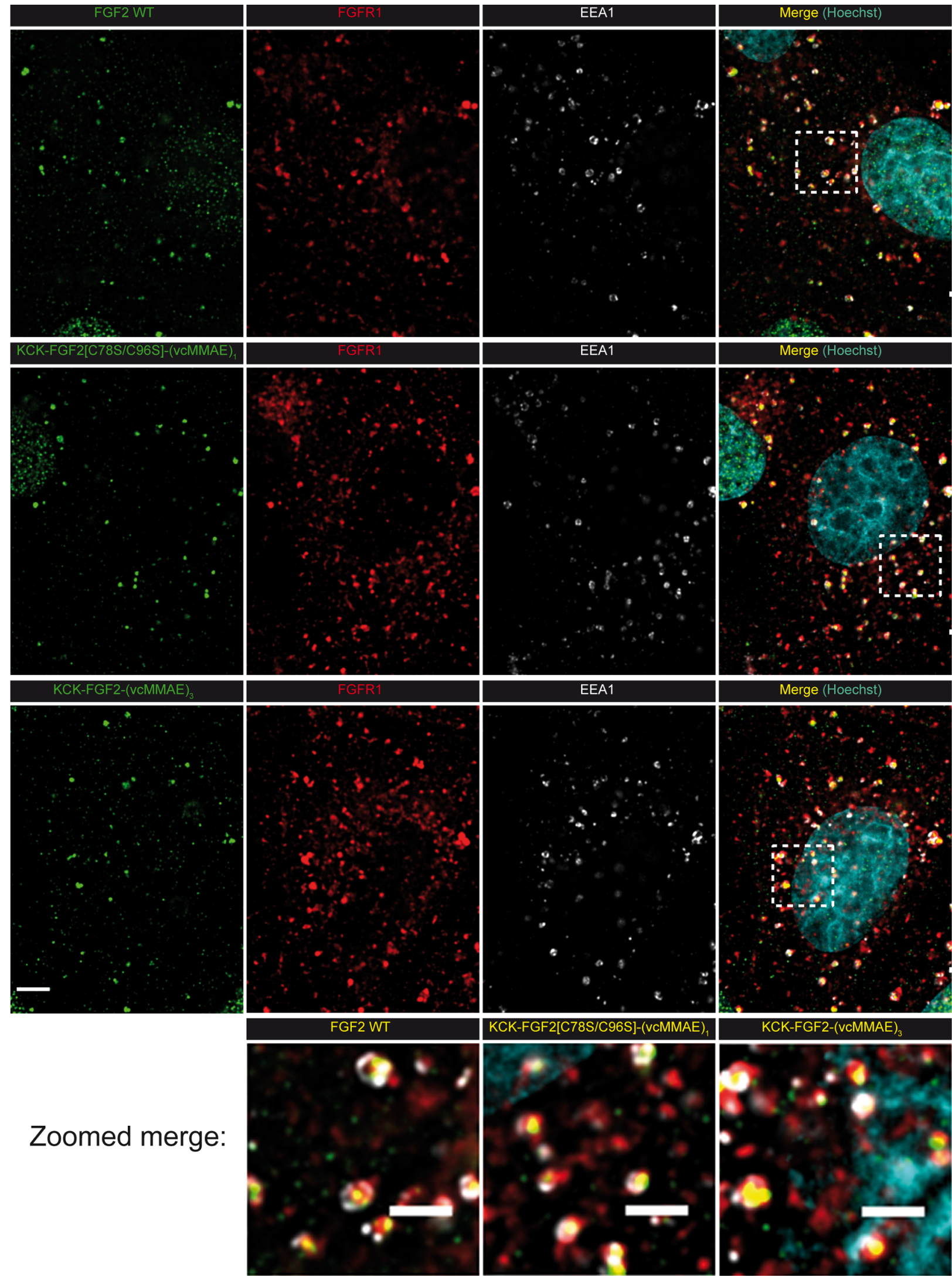

Figure 6. Widefield immunofluorescence microscopy imaging of endocytosed FGF2 WT and FGF2-vcMMAE conjugates in U2OS-R1 cells. U2OSR1 cells cultured on glass coverslips were incubated with $500 \mathrm{ng} / \mathrm{mL}$ FGF2 WT, KCK-FGF2[C78S/C96S]-(vcMMAE) ${ }_{1}$, or KCK-FGF2(vcMMAE) $)_{3}$ at $37^{\circ} \mathrm{C}$ for $40 \mathrm{~min}$ to allow for endocytosis. The cells were stained with anti-FGF2 (green), anti-FGFR1 (red), and anti-EEA1 (white) antibodies and with Hoechst 33342 to visualize DNA. Images were deconvolved and single optical sections are shown, either as single-channel (color) images or as overlays as indicated. The bar corresponds to $4 \mu \mathrm{m}$, and in zoomed images, to $2 \mu \mathrm{m}$. The squares marked in four-color overlay images indicate blown-up regions shown in the bottom row. 

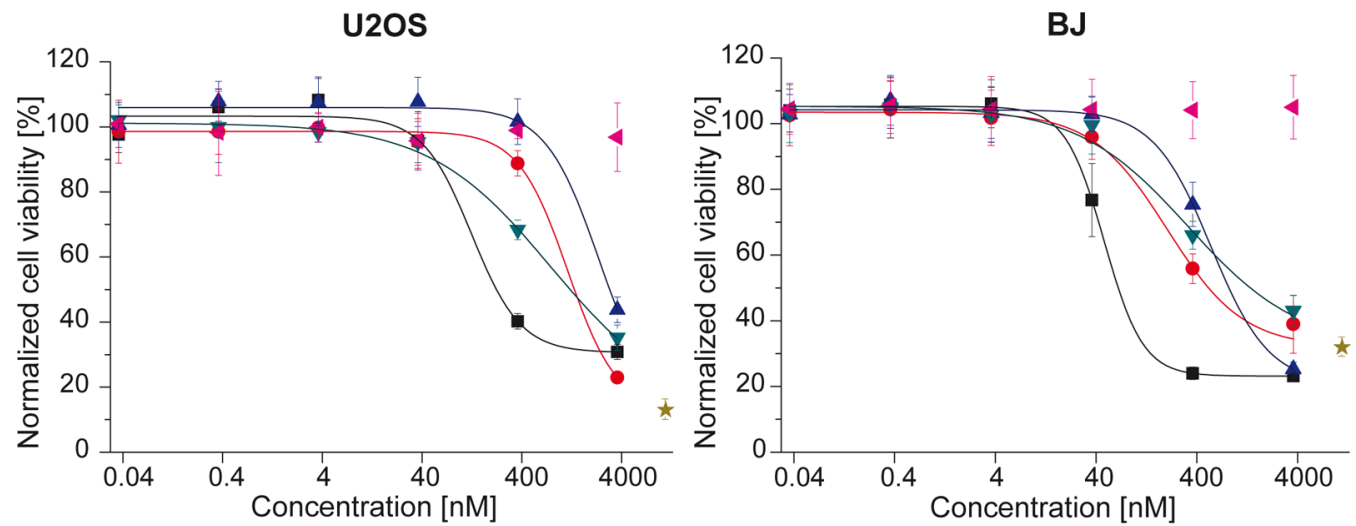

U2OS-R1

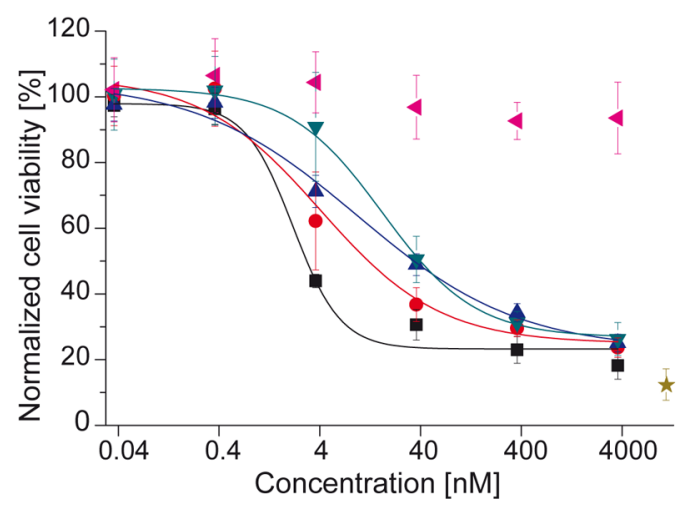

- KCK-FGF2-(VCMMAE)

- FGF2-(vcMMAE)

- KCK-FGF2[C78S/C96S]-(vcMMAE)

$\checkmark$ FGF2[C78S/C96S]-KCK-(VCMMAE)

4 FGF2 WT

$\star$ MMAE 11 uM

Figure 7. Viability of cells treated with the FGF2 WT and FGF2-vcMMAE conjugates. BJ, U2OS, and U2OS-R1 cells were treated with indicated agents at various concentrations for $96 \mathrm{~h}$, and their viability was assessed with the Alamar Blue assay. For comparison, the effect of free $11 \mu \mathrm{M}$ MMAE is shown. Results shown are mean values from three experiments \pm SD. The solid lines represent Hill equation fits.

Table 2. Toxicity of the FGF2-vcMMAE Conjugates in BJ, U2OS, and U2OS-R1 Cells

\begin{tabular}{lccr} 
& \multicolumn{3}{c}{ cell line } \\
\cline { 2 - 4 } \multicolumn{1}{c}{ conjugate } & $\mathrm{BJ}$ & $\mathrm{U} 2 \mathrm{OS}$ & $\mathrm{U} 2 \mathrm{OS}-\mathrm{R} 1$ \\
$\mathrm{EC}_{50}[\mathrm{nM}]$ & $\mathrm{EC}_{50}[\mathrm{nM}]$ & $125.7 \pm 47.5$ & $\mathrm{EC}_{50}[\mathrm{nM}]$ \\
KCK-FGF2-(vcMMAE) & $48.2 \pm 2.4$ & $1152.2 \pm 56.5$ & $2.2 \pm 0.9$ \\
FGF2-(vcMMAE) & $204.2 \pm 23.0$ & $2358.3 \pm 311.6$ & $4.1 \pm 3.5$ \\
KCK-FGF2[C78S/C96S]-(vcMMAE) & $450.6 \pm 169.9$ & $9.4 \pm 5.4$ \\
FGF2[C78S/C96S]-KCK-(vcMMAE) & $328.7 \pm 53.3$ & $774.6 \pm 57.2$ & $16.7 \pm 2.9$
\end{tabular}

to FGF1 and FGF2, ${ }^{49,50}$ and two toxin conjugates. Wiedlocha et al. formed an FGF1-diphteria toxin A chain fusion to study the structural requirements for the translocation of this growth factor into the cell. ${ }^{51}$ In another study, a fusion protein composed of FGF2 and ribosome-inactivating protein, saporin, was shown to be cytotoxic in melanoma and bladder cell lines. ${ }^{52,53}$ As far as we know, only our group has demonstrated successful conjugation of a FGF family member (FGF1) to a cytotoxic drug (MMAE), achieving effective killing of cells overexpressing the FGFR. ${ }^{13,14}$

We propose to use FGF2 as a targeting molecule alternatively to antibodies to overcome some limitations of $\mathrm{ADC}$ technology. To obtain an antibody or antibody fragment highly specific to a unique antigen presented on cancer cells, laborious and expensive selection procedures are required. Also, it has to be kept in mind that high specificity and affinity of antibodies to cell-surface receptors may not be enough to provide their effective internalization and, in consequence, drug delivery to the target cell. ${ }^{54,55}$ Moreover, even humanized antibodies may evoke strong immunogenicity, questioning their therapeutic application. ${ }^{56}$ As a natural ligand, FGF2 does not generate immune response, binds strongly to specific FGFRs, and is efficiently internalized and directed to lysosomes, where it can release a cytotoxic payload. Production of recombinant FGF2 is easy, and this protein can be optimized for therapeutic purposes by protein engineering methods. Besides the abovementioned FGFR1-related cancers, FGF2 could be used to target tumors overexpressing FGFR3c, including colorectal, ${ }^{57}$ or FGFR4, such as pancreatic adenocarcinoma, ${ }^{58}$ colorectal, ${ }^{59}$ and ovarian cancer. ${ }^{60}$ Relatively broad specificity of FGF2 may generate side effects, affecting the normal cells, but usually the number of FGFR molecules in FGFR-dependent tumors is much higher than the physiological level found in healthy tissues. $^{61}$

FGF2 offers major advantage over FGF1. It contains two exposed and reactive cysteines which, owing to the low tendency of FGF2 to unfold, can be substituted with two MMAE molecules without disturbing the protein's structure and biological activity. A doubly loaded FGF2 conjugate did not show any tendency to aggregate and preserved its native 
conformation, as assessed by fluorescence emission spectra that are very sensitive to changes in the tertiary structure. ${ }^{27,62}$ This result encouraged us to increase the cytotoxic drug loading by introduction of a third MMAE molecule on an FGF2 Nterminus by extending it with a linker containing the Lys-CysLys sequence. Notably, although both $\mathrm{N}$ - and C-terminally extended FGF2 variants were stable, upon vcMMAE conjugation, the latter formed aggregates, which precluded its further study. Thus, we obtained two singly substituted conjugates, one containing two MMAE molecules and one with the DPR = 3 (Figure 1). We found that all of them activated the main intracellular signaling cascade similarly to FGF2 WT, proving that attachment of even three MMAE moieties did not affect the FGF2 binding to its receptor. We also confirmed that the FGF2 conjugates were efficiently internalized, reaching first early endosomes and then lysosomes and enabling the release of the drug inside the cell. This feature is a prerequisite for effective action of targeted drug conjugates. $^{63,64}$

To assess the cytotoxicity of the conjugates, we used U2OSR1 cells overexpresing FGFR1 and BJ cells, which are normal human fibroblasts expressing FGFR1 at a moderate level, together with untransfected U2OS cells that express a marginal level of FGFR1 and served as a control. ${ }^{13}$ The cells overexpressing the receptor (U2OS-R1) were killed much more efficiently than $\mathrm{BJ}$ cells (the $\mathrm{EC}_{50}(\mathrm{BJ}) / \mathrm{EC}_{50}(\mathrm{U} 2 \mathrm{OS}-\mathrm{R} 1$ ) ratio over 20), and U2OS cells with little FGFRs were destroyed at several-fold higher concentrations of the conjugate than BJ cells. These results confirmed not only the high cytotoxic effect of the FGF2 conjugates in cells producing FGFR1 but also its correlation with the FGFR1 expression level.

For the most toxic FGF2 conjugate, that triply substituted with MMAE, the EC50 toward U2OS-R1 cells equalled to 2.2 nM. The singly substituted FGF2 conjugate at the $\mathrm{N}$-terminus was over 4 times more potent in killing U2OS-R1 cells than the corresponding conjugate of FGF1 described previously. ${ }^{13}$ Moreover, the FGF2 conjugate was less toxic to control cells (U2OS), providing a wider (by almost 1 order of magnitude) therapeutic window.

The construction of stable FGF2 conjugates with different numbers of MMAE molecules attached $(1,2$, or 3$)$ allowed us also to establish the dependence of their cytotoxicity effect on the DPR. In both cell lines, U2OS-R1 and BJ, the conjugates with a higher DPR were more toxic than the less-loaded ones. Although the accuracy of the $\mathrm{EC}_{50}$ estimation is not high, one may conclude that introduction of an additional MMAE moiety results in an about 2-fold increase of the cytotoxic efficiency (Table 2). A similar tendency has been observed for ADCs. ${ }^{65}$ Recently, this effect was noticed also in in vivo studies on antiCD30 antibodies and trastuzumab conjugates with MMAE. ${ }^{66}$ To conclude, we have obtained defined cytotoxic conjugates of FGF2 and MMAE, which undergo effective endocytosis and reveal high toxicity in cells overexpressing FGFR. Moreover, we have shown that the cell-killing activity of such conjugates is strongly affected by drug loading.

\section{EXPERIMENTAL PROCEDURES}

Materials and Methods. Antibodies and Reagents. The following primary antibodies were used: rabbit anti-p44/42 MAPK (\#9102) and mouse anti-phospho-p44/42 MAPK (Thr202/Tyr204) (\#9106) from Cell Signalling Technology (Danvers, MA); mouse anti- $\gamma$-tubulin (T6557) from Sigma-
Aldrich (St. Louis, MO); rabbit anti-EEA1 antibody (2411S) and mouse anti-EEA1 (610456) from BD Biosciences Transduction Laboratories (Lexington, KY); goat anti-FGF2 (sc1390) from Santa Cruz Biotechnology (Dallas, TX); rabbit anti-FGFR1 (EPR806Y) from Epitomics (Burlingame, CA); and rabbit anti-phospho-FGFR1 (Tyr653/Tyr654) (06-1433) from EMD Millipore (Germany). Secondary antibodies were as follows: goat antimouse and antirabbit conjugated to HRP and donkey antigoat, antirabbit, or antimouse coupled to fluorophores AlexaFluor-488, -568, or -647 were from Jackson ImmunoResearch Laboratories (West Grove, PA). The following dyes were used: DyLight 550 NHS Ester, Hoechst 33342, DAPI, CellTrace Violet, and ProLong Gold Antifade Mountant were from Thermo Fisher Scientific (Waltham, MA). Immobilon-PSQ PVDF $0.2 \mu \mathrm{m}$ membranes were from EMD Millipore (Germany), Dulbecco's PBS and heparin sodium salt from porcine intestinal mucosa was from Sigma-Aldrich, and Alamar Blue was from Thermo Fisher Scientific (Waltham, MA).

HiTrap Heparin HP columns were from GE Healthcare (U.K.), and Zeba Spin Desalting columns were from Thermo Fisher Scientific. MMAE and vcMMAE were from MedChem Express (Monmouth Junction, NJ). All other reagents were obtained from Sigma-Aldrich.

Cell Lines. BJ cells (CRL-2522) were grown in Eagle's Minimum Essential Medium from Sigma-Aldrich. U2OS (HTB-96) and U2OS stably transfected with FGFR1 (U2OSR1) were grown in McCoy's 5A Modified Medium from Lonza (Switzerland). All media were supplemented with $10 \%$ fetal bovine serum from Thermo Fisher Scientific, and 1\% penicillin/streptomycin mix was from BioWest (France). Additionally, the U2OS-R1 cell medium contained $50 \mu \mathrm{g} / \mathrm{mL}$ gentamicin sulfate from Thermo Fisher Scientific. All cell lines were cultured in a humidified incubator at $37{ }^{\circ} \mathrm{C}$ in $5 \% \mathrm{CO}_{2}$ atmosphere. The $\mathrm{BJ}$ and $\mathrm{U} 2 \mathrm{OS}$ cell lines were obtained from American Type Culture Collection (Manassas, VA). The U2OS cells stably expressing FGFR1 (U2OS-R1) were a kind gift from Dr. Ellen M. Haugsten from The Norwegian Radium Hospital. $^{44}$

Plasmids. The sequence encoding human FGF2 (residues $1-155)$ was cloned into the $\mathrm{pET}-3 \mathrm{c}$ expression vector from Stratagene (La Jolla, CA). N- and C-terminal linkers KCKSGG and GGSKCK and point mutations C78S and C96S were introduced using a QuikChange Site-Directed Mutagenesis Kit from Agilent Technologies (Santa Clara, CA), according to the manufacturer's protocol. Four variants differing in the number of modifiable cysteines were constructed to enable the synthesis of conjugates with different numbers of drug molecules.

Protein Expression and Purification. Proteins were expressed in an E. coli Rosetta 2(DE3)pLysS expression strain from Novagen-EMD Biosciences (Madison, WI). Bacteria were grown in a TB medium with $100 \mu \mathrm{g} / \mathrm{mL}$ ampicillin at $37{ }^{\circ} \mathrm{C}$ to $\mathrm{OD}_{600}=0.6$. Then, the protein expression was induced by the addition of IPTG to a final concentration of $0.3 \mathrm{mM}$ and the culture was incubated at $25{ }^{\circ} \mathrm{C}$ for $12 \mathrm{~h}$. Next, bacteria were harvested by centrifugation at $8000 \mathrm{~g}$, resuspended in lysis buffer ( $50 \mathrm{mM}$ monosodium phosphate, $0.15 \mathrm{M} \mathrm{NaCl}, 1 \mathrm{mM}$ DTT, 1 mM EDTA, $0.1 \%$ Triton X-100, 1 mM PMSF, pH 7.2), and homogenized using French press. The cell lysate was centrifuged at $50000 \mathrm{~g}$ at $4{ }^{\circ} \mathrm{C}$ for $1 \mathrm{~h}$. The supernatant was diluted in binding buffer ( $50 \mathrm{mM}$ monosodium phosphate, 0.7 $\mathrm{M} \mathrm{NaCl}, 1 \mathrm{mM}$ DTT, $1 \mathrm{mM}$ EDTA, $\mathrm{pH}$ 7.2) and loaded on a HiTrap Heparin HP column. The column was washed with 
washing buffer ( $50 \mathrm{mM}$ monosodium phosphate, $1.0 \mathrm{M} \mathrm{NaCl}$, $1 \mathrm{mM}$ DTT, $1 \mathrm{mM}$ EDTA, $\mathrm{pH}$ 7.2), and proteins were eluted with a linear 1.0-2.0 M gradient of $\mathrm{NaCl}$ in the same buffer.

Conjugation of FGF2 Variants with vCMMAE. Purified proteins were desalted to reaction buffer $(50 \mathrm{mM}$ monosodium phosphate, $10 \mathrm{mM} \mathrm{Na}_{2} \mathrm{SO}_{4}, 10 \mathrm{mM}$ methionine, $1 \mathrm{mM}$ EDTA, $\mathrm{pH}$ 7.0) using Zeba Spin Desalting columns. A maleimide derivative of MMAE (vcMMAE) dissolved in $N, N$-dimethylacetamide (DMAc) at $50 \mathrm{mg} / \mathrm{mL}$ was added to protein solutions $(1.5 \mathrm{mg} / \mathrm{mL})$ to give a 2 -fold molar excess of the drug over protein $-\mathrm{SH}$ groups. The conjugation reaction mixture was incubated for $1 \mathrm{~h}$ at $20^{\circ} \mathrm{C}$. Reaction progress was monitored by SDS-PAGE and MALDI-time-of-flight (TOF) MS. Finally, the excess of unconjugated vcMMAE was removed from the reaction mixture by buffer exchange to Dulbecco's PBS using Zeba Spin Desalting columns.

Fluorescence Labeling of Proteins and Conjugates with DyLight 550. Unmodified wild-type FGF2 and two FGF2vcMMAE conjugates were labeled with DyLight 550. DyLight $550(1 \mu \mathrm{L})$ at a concentration of $1 \mathrm{mg} / \mathrm{mL}$ NHS Ester in DMAc was added to $100 \mu \mathrm{L}$ of purified proteins or conjugates at a concentration of $1 \mathrm{mg} / \mathrm{mL}$ in $50 \mathrm{mM}$ monosodium

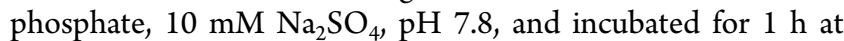
room temperature (RT) in the dark. The labeled products were purified on Zeba Spin Desalting columns to remove unreacted dye.

MS. Molecular masses of proteins and their conjugates were verified by MALDI-TOF MS (Applied Biosystems AB 4800+) using $\alpha$-cyano-4-hydroxycinnamic acid as a matrix.

Spectrofluorimetry. The folded state of proteins and their conjugates was verified by spectrofluorimetry. The fluorescence spectra were acquired using an FP-8500 spectrofluorimeter (Jasco, Japan) with excitation at $280 \mathrm{~nm}$ and emission in the $300-450 \mathrm{~nm}$ range, at a protein concentration of $\sim 4 \times 10^{-6} \mathrm{M}$ in Dulbecco's PBS.

Activation of FGF2 Signaling Pathways. Serum-starved $\mathrm{NIH} 3 \mathrm{~T} 3$ cells were stimulated for $15 \mathrm{~min}$ with $100 \mathrm{ng} / \mathrm{mL}$ FGF2 variants or their conjugates in the presence of heparin $(10 \mathrm{U} / \mathrm{mL})$. The cells were then washed with PBS, lysed with Laemmli Sample Buffer, and sonicated. The total cell lysate was separated by SDS-PAGE (12\%) and analyzed by Western blotting using the following antibodies: anti-FGFR1, antiphospho-FGFR1, anti-phospho-p44/42 MAPK, anti-p44/42 MAPK, and anti- $\gamma$-tubulin. All primary antibodies were used at the $1: 1000$ dilution. Specific protein bands were visualized with HRP-conjugated secondary antibodies and an enhanced chemoluminescence substrate using ChemiDoc station (BioRad, Hercules, CA).

BLI Analysis of Binding of FGF2 Conjugates to FGFR1C. Binding measurements were performed using ForteBio Octet K2 (Pall ForteBio, Fremont, CA) and high-precision Streptavidin biosensors (SAX) (Pall ForteBio, Fremont, CA). Studies of interactions between biotinylated extracellular domains of FGFR1c fused to Fc fragments and wild-type FGF2 or FGF2 conjugates were performed at $25{ }^{\circ} \mathrm{C}$ in PBS supplemented with $0.2 \%(\mathrm{w} / \mathrm{v})$ BSA, $0.1 \%(\mathrm{w} / \mathrm{v})$ PEG $3.5 \mathrm{kDa}$, $0.05 \%(\mathrm{v} / \mathrm{v})$ Triton $\mathrm{X}-100$, and $10 \mathrm{mM}\left(\mathrm{NH}_{4}\right)_{2} \mathrm{SO}_{4}$. Sensor tips were hydrated in buffer for $30 \mathrm{~min}$ prior to use. The wells in 96microwell plates were filled with $200 \mu \mathrm{L}$ of either buffer or sample and incubated for $10 \mathrm{~min}$ at $25{ }^{\circ} \mathrm{C}$ for system stabilization. Next, biotinylated FGFR1c was immobilized on the SAX sensor for $300 \mathrm{~s}$ and the sensor was blocked with biocytin $(0.04 \mathrm{mg} / \mathrm{mL})$ for $300 \mathrm{~s}$ and washed for $60 \mathrm{~s}$. A reference sensor without the biotinylated receptor served as a background control. Association of the wild-type FGF2 and FGF2 conjugates at different concentrations (20,40, and 80 $\mathrm{nM}$ ) was carried out for $200 \mathrm{~s}$, and the dissociation was monitored for $200 \mathrm{~s}$. Kinetic parameters were calculated using a simple 1:1 Langmuir model with BIAevaluation 4.1 software.

Cell Viability Assays. Cells cultured in 96-well plates (5000 cells/well in the required media supplemented with $10 \mathrm{U} / \mathrm{mL}$ heparin) were treated with different concentrations of wild-type FGF2 or its cytotoxic conjugates. After $96 \mathrm{~h}$ of continuous exposure to the drug, the medium was removed and replaced with the fresh medium containing 10\% Alamar Blue. Fluorescence emission at $590 \mathrm{~nm}$ (excitation at $560 \mathrm{~nm}$ ), reflecting the viability of the cells, was measured $4 \mathrm{~h}$ later using an EnVision Multilabel Reader fluorescence plate reader (PerkinElmer, Waltham, MA). The data were fitted to the Hill equation using Origin 7 software (Northampton, MA) to calculate $\mathrm{EC}_{50}$ values.

Confocal Microscopy. U2OS cells stained with CellTrace Violet according to the manufacturer's protocol were seeded on coverslips with equal number of nonstained U2OS-R1 cells and grown together to $70 \%$ confluence. The cells were then incubated with $1000 \mathrm{ng} / \mathrm{mL}$ wild-type FGF2 or FGF2vcMMAE conjugate labeled with DyLight 550 in the presence of $10 \mathrm{U} / \mathrm{mL}$ heparin at $37{ }^{\circ} \mathrm{C}$ for $15 \mathrm{~min}$. Then, the cells were washed with PBS, fixed in $4 \%$ formaldehyde for $15 \mathrm{~min}$ at RT, permeabilized in $0.5 \%$ Triton X-100 for $10 \mathrm{~min}$ at $4{ }^{\circ} \mathrm{C}$, and blocked with blocking buffer (1\% BSA, 10\% normal goat serum, $0.2 \%$ Tween-20, and $0.3 \mathrm{M}$ glycine in PBS) for $1 \mathrm{~h}$ at RT. Next, the cells were incubated with primary rabbit anti-EEA1 antibody overnight at $4{ }^{\circ} \mathrm{C}$ and then with an AlexaFluor-488conjugated goat antirabbit secondary antibody at RT for $1 \mathrm{~h}$. Nuclei were stained with DAPI, and the coverslips were mounted with a ProLong Gold antifade mountant. The cell staining was analyzed using a Cell Observer SD confocal system (Zeiss, Germany) equipped with an EMCCD QImaging Rolera EM-C2 camera with a $40 \times$ oil immersion objective. Images were processed in Fiji software. ${ }^{67}$

Widefield Immunofluorescence Microscopy. U2OS-R1 cells grown on coverslips were incubated with $500 \mathrm{ng} / \mathrm{mL}$ FGF2 conjugates or unconjugated wild-type FGF2 in HEPES medium supplemented with $50 \mathrm{U} / \mathrm{mL}$ heparin at $37^{\circ} \mathrm{C}$ for 40 min and then fixed with $4 \%$ formaldehyde in PBS. The fixed cells were treated with $0.05 \%$ saponin for permeabilization and then stained with primary antibodies; goat anti-FGF2, rabbit anti-FGFR1, and mouse anti-EEA1; followed by secondary antibodies (donkey anti-goat, -rabbit, and -mouse) coupled to AlexaFluor-488, -568, or -647; and with Hoechst 33342 to stain DNA. The coverslips were mounted with the ProLong Gold antifade mountant and viewed under a Deltavision OMX V4 microscope (GE Healthcare, U.K.) equipped with an Olympus 60× NA 1.42 Plan Apochromat objective, an InSightSSI widefield illumination module, and three cooled sCMOS cameras. Four-channel images including $\mathrm{z}$-stacks covering the whole cell of interest were recorded. Raw data images were deconvolved and aligned using Softworx software (GE Healthcare, U.K.). For illustrations, a single optical section was chosen and images were processed in Fiji software. ${ }^{67}$

\section{ASSOCIATED CONTENT}

S Supporting Information

The Supporting Information is available free of charge on the ACS Publications website at DOI: 10.1021/acsomega.7b00116. 
DPR analysis by reverse-phase high-performance liquid chromatography; colocalization of FGF2 conjugates with lysosomes by structured illumination microscopy (SIM); quantification of the FGFR1 level in U2OS-R1, BJ, and cell lines; flow cytometry analysis of binding of FGF2 and FGF2 conjugate to U2OS-R1, BJ, and U2OS cells (PDF)

\section{AUTHOR INFORMATION}

\section{Corresponding Author}

*E-mail: jacek.otlewski@uwr.edu.pl.

\section{ORCID}

Mateusz Adam Krzyscik: 0000-0002-9464-3829

Michal Lobocki: 0000-0003-2577-1410

Jacek Otlewski: 0000-0001-8630-2891

\section{Notes}

The authors declare no competing financial interest.

\section{ACKNOWLEDGMENTS}

This work was supported by the Polish-Norwegian Research Programme operated by the National Centre for Research and Development under the Norwegian Financial Mechanism 2009-2014 in the frame of Project Contract No. Pol-Nor/ 197969/50/2013. We thank Dr. Grzegorz Chodaczek (from Wroclaw Research Centre EIT+) for acquiring confocal images, Dr. Ellen M. Haugsten (from the Institute for Cancer Research) for providing the stably transfected U2OS-R1 cell line, Dr. Alicja Sochaj-Gregorczyk for help with genetic constructs, and Dr. Agnieszka Kubiak for assistance in cell culture maintenance.

\section{ABBREVIATIONS}

$\mathrm{ADC}$, antibody-drug conjugate; $\mathrm{BLI}$, biolayer interferometry; FGF, fibroblast growth factor; FGFR, fibroblast growth factor receptor; MMAE, monomethyl auristatin E; vcMMAE, maleimidocaproyl-Val-Cit-PABC-monomethylauristatin E; $\mathrm{DPR}$, drug-to-protein ratio

\section{REFERENCES}

(1) Strebhardt, K.; Ullrich, A. Paul Ehrlich's magic bullet concept: 100 years of progress. Nat. Rev. Cancer 2008, 8, 473-480.

(2) Park, K. Drug Delivery Research: The Invention Cycle. Mol. Pharm. 2016, 13, 2143-2147.

(3) Lambert, J. M. Drug-conjugated antibodies for the treatment of cancer. Br. J. Clin. Pharmacol. 2013, 76, 248-262.

(4) Beck, A.; Reichert, J. M. Antibody-drug conjugates. MAbs 2014, 6, 15-17.

(5) Diamantis, N.; Banerji, U. Antibody-drug conjugates-an emerging class of cancer treatment. Br. J. Cancer 2016, 114, 362-367.

(6) Chames, P.; Van Regenmortel, M.; Weiss, E.; Baty, D. Therapeutic antibodies: successes, limitations and hopes for the future. Br. J. Pharmacol. 2009, 157, 220-233.

(7) Acton, Q. A. Serum Globulins-Advances in Research and Application, 2013th ed., 2013, ScholarlyEditions.

(8) Turner, N.; Grose, R. Fibroblast growth factor signalling: from development to cancer. Nat. Rev. Cancer 2010, 10, 116-129.

(9) Wesche, J.; Haglund, K.; Haugsten, E. M. Fibroblast growth factors and their receptors in cancer. Biochem. J. 2011, 437, 199-213.

(10) Qing, J.; Du, X.; Chen, Y.; Chan, P.; Li, H.; Wu, P.; Marsters, S.; Stawicki, S.; Tien, J.; Totpal, K.; Ross, S.; Stinson, S.; Dornan, D.; French, D.; Wang, Q.-R.; Stephan, J.-P.; Wu, Y.; Wiesmann, C.; Ashkenazi, A. Antibody-based targeting of FGFR3 in bladder carcinoma and $\mathrm{t}(4 ; 14)$-positive multiple myeloma in mice. J. Clin. Invest. 2009, 119, 1216-1229.
(11) Dieci, M. V.; Arnedos, M.; Andre, F.; Soria, J. C. Fibroblast Growth Factor Receptor Inhibitors as a Cancer Treatment: From a Biologic Rationale to Medical Perspectives. Cancer Discovery 2013, 3, 264-279.

(12) Jo, J. C.; Choi, E. K.; Shin, J. S.; Moon, J. H.; Hong, S. W.; Lee, H. R.; Kim, S. M.; Jung, S. A.; Lee, D. H.; Jung, S. H.; Lee, S. H.; Kim, J. E.; Kim, K. P.; Hong, Y. S.; Suh, Y. A.; Jang, S. J.; Choi, E. K.; Lee, J. S.; Jin, D. H.; Kim, T. W. Targeting FGFR Pathway in Human Hepatocellular Carcinoma: Expressing pFGFR and pMET for Antitumor Activity. Mol. Cancer Ther. 2015, 14, 2613-2622.

(13) Szlachcic, A.; Zakrzewska, M.; Lobocki, M.; Jakimowicz, P.; Otlewski, J. Design and characteristics of cytotoxic fibroblast growth factor 1 conjugate for fibroblast growth factor receptor-targeted cancer therapy. Drug Des., Dev. Ther. 2016, 10, 2547-2560.

(14) Lobocki, M.; Zakrzewska, M.; Krzyscik, M. A.; Szlachcic, A.; Sokolowska-Wedzina, A.; Otlewski, J. High yield generation and characterization of site specific FGF1-MMAE conjugate. Bioconjugate Chem. 2017, DOI: 10.1021/acs.bioconjchem.7b00158.

(15) Vemuri, S.; Beylin, I.; Sluzky, V.; Stratton, P.; Eberlein, G.; Wang, Y. J. The Stability of bFGF Against Thermal Denaturation. J. Pharm. Pharmacol. 1994, 46, 481-486.

(16) Blaber, S. I.; Culajay, J. F.; Khurana, A.; Blaber, M. Reversible Thermal Denaturation of Human FGF-1 Induced by Low Concentrations of Guanidine Hydrochloride. Biophys. J. 1999, 77, $470-477$.

(17) Chen, G.; Gulbranson, D. R.; Yu, P.; Hou, Z.; Thomson, J. A. Thermal Stability of Fibroblast Growth Factor Protein Is a Determinant Factor in Regulating Self-Renewal, Differentiation, and Reprogramming in Human Pluripotent Stem Cells. Stem Cells 2012, 30, 623-630.

(18) Buchtova, M.; Chaloupkova, R.; Zakrzewska, M.; Vesela, I.; Cela, P.; Barathova, J.; Gudernova, I.; Zajickova, R.; Trantirek, L.; Martin, J.; Kostas, M.; Otlewski, J.; Damborsky, J.; Kozubik, A.; Wiedlocha, A.; Krejci, P. Instability restricts signaling of multiple fibroblast growth factors. Cell. Mol. Life Sci. 2015, 72, 2445-2459.

(19) Ornitz, D. M.; Xu, J.; Colvin, J. S.; McEwen, D. G.; MacArthur, C. A.; Coulier, F.; Gao, G.; Goldfarb, M. Receptor specificity of the fibroblast growth factor family. J. Biol. Chem. 1996, 271, 15292-7.

(20) Zhang, X.; Ibrahimi, O. A.; Olsen, S. K.; Umemori, H.; Mohammadi, M.; Ornitz, D. M. Receptor Specificity of the Fibroblast Growth Factor Family: The Complete Mammalian Fgf Family. J. Biol. Chem. 2006, 281, 15694-15700.

(21) Olsnes, S.; Klingenberg, O.; Wiedlocha, A. Transport of Exogenous Growth Factors and Cytokines to the Cytosol and to the Nucleus. Physiol. Rev. 2003, 83, 163-182.

(22) Małecki, J.; Wesche, J.; Skjerpen, C. S.; Wiedłocha, A.; Olsnes, S. Translocation of FGF-1 and FGF-2 across Vesicular Membranes Occurs during G1-Phase by a Common Mechanism. Mol. Biol. Cell 2004, 15, 801-814.

(23) Ducry, L.; Stump, B. Antibody-Drug Conjugates: Linking Cytotoxic Payloads to Monoclonal Antibodies. Bioconjugate Chem. 2010, 21, 5-13.

(24) Eriksson, A. E.; Matthews, B. W.; Cousens, L. S. Refinement of the structure of human basic fibroblast growth factor at $1.6 \AA$ resolution and analysis of presumed heparin binding sites by selenate substitution. Protein Sci. 1993, 2, 1274-1284.

(25) Senter, P. D. Potent antibody drug conjugates for cancer therapy. Curr. Opin. Chem. Biol. 2009, 13, 235-244.

(26) Wakankar, A.; Chen, Y.; Gokarn, Y.; Jacobson, F. S. Analytical methods for physicochemical characterization of antibody drug conjugates. MAbs 2011, 3, 161-172.

(27) Estapé, D.; Heuvel, J. v. d.; Rinas, U. Susceptibility towards intramolecular disulphide-bond formation affects conformational stability and folding of human basic fibroblast growth factor. Biochem. J. 1998, 335, 343-349.

(28) Schrama, D.; Reisfeld, R. A.; Becker, J. C. Antibody targeted drugs as cancer therapeutics. Nat. Rev. Drug Discovery 2006, 5, 147159 . 
(29) Scott, A. M.; Wolchok, J. D.; Old, L. J. Antibody therapy of cancer. Nat. Rev. Cancer 2012, 12, 278-287.

(30) Sliwkowski, M. X.; Mellman, I. Antibody Therapeutics in Cancer. Science 2013, 341, 1192-1198.

(31) Smith, A. D.; Roda, D.; Yap, T. A. Strategies for modern biomarker and drug development in oncology. J. Hematol. Oncol. 2014, 7, 70.

(32) Wagner, E.; Curiel, D.; Cotten, M. Delivery of drugs, proteins and genes into cells using transferrin as a ligand for receptor-mediated endocytosis. Adv. Drug Delivery Rev. 1994, 14, 113-135.

(33) Hartmann, L. C.; Keeney, G. L.; Lingle, W. L.; Christianson, T. J. H.; Varghese, B.; Hillman, D.; Oberg, A. L.; Low, P. S. Folate receptor overexpression is associated with poor outcome in breast cancer. Int. J. Cancer 2007, 121, 938-942.

(34) O’Shannessy, D. J.; Somers, E. B.; Maltzman, J.; Smale, R.; Fu, Y.-S. Folate receptor alpha (FRA) expression in breast cancer: identification of a new molecular subtype and association with triple negative disease. Springerplus 2012, 1, 22.

(35) Bandara, N. A.; Hansen, M. J.; Low, P. S. Effect of Receptor Occupancy on Folate Receptor Internalization. Mol. Pharm. 2014, 11, 1007-1013.

(36) Necela, B. M.; Crozier, J. A.; Andorfer, C. A.; Lewis-Tuffin, L.; Kachergus, J. M.; Geiger, X. J.; Kalari, K. R.; Serie, D. J.; Sun, Z.; Aspita, A. M.; O'Shannessy, D. J.; Maltzman, J. D.; McCullough, A. E.; Pockaj, B. A.; Cunliffe, H. E.; Ballman, K. V.; Thompson, E. A.; Perez, E. A. Folate Receptor- $\alpha$ (FOLR1) Expression and Function in Triple Negative Tumors. PLoS One 2015, 10, No. e0122209.

(37) Yang, R.; Tang, Q.; An, Y.; Miao, F.; Liu, P.; Li, M. Preparation of folic acid-conjugated, doxorubicin-loaded, magnetic bovine serum albumin nanospheres and their antitumor effects in vitro and in vivo. Int. J. Nanomed. 2014, 9, 4231.

(38) He, Z.; Huang, J.; Xu, Y.; Zhang, X.; Teng, Y.; Huang, C.; Wu, Y.; Zhang, X.; Zhang, H.; Sun, W. Co-delivery of cisplatin and paclitaxel by folic acid conjugated amphiphilic PEG-PLGA copolymer nanoparticles for the treatment of non-small lung cancer. Oncotarget 2015, 6, 42150-42168.

(39) Schmitz, K.; Schildhaus, H. Clinical significance of FGFR1 gene amplification in lung cancer patients. Lung Cancer Manage. 2014, 3, 305-314.

(40) Weiss, J.; Sos, M. L.; Seidel, D.; Peifer, M.; Zander, T.; Heuckmann, J. M.; Ullrich, R. T.; Menon, R.; Maier, S.; Soltermann, A.; Moch, H.; Wagener, P.; Fischer, F.; Heynck, S.; Koker, M.; Schottle, J.; Leenders, F.; Gabler, F.; Dabow, I.; Querings, S.; Heukamp, L. C.; Balke-Want, H.; Ansen, S.; Rauh, D.; Baessmann, I.; Altmuller, J.; Wainer, Z.; Conron, M.; Wright, G.; Russell, P.; Solomon, B.; Brambilla, E.; Brambilla, C.; Lorimier, P.; Sollberg, S.; Brustugun, O. T.; Engel-Riedel, W.; Ludwig, C.; Petersen, I.; Sanger, J.; Clement, J.; Groen, H.; Timens, W.; Sietsma, H.; Thunnissen, E.; Smit, E.; Heideman, D.; Cappuzzo, F.; Ligorio, C.; Damiani, S.; Hallek, M.; Beroukhim, R.; Pao, W.; Klebl, B.; Baumann, M.; Buettner, R.; Ernestus, K.; Stoelben, E.; Wolf, J.; Nurnberg, P.; Perner, S.; Thomas, R. K. Frequent and Focal FGFR1 Amplification Associates with Therapeutically Tractable FGFR1 Dependency in Squamous Cell Lung Cancer. Sci. Transl. Med. 2010, 2, 62ra93.

(41) Heinzle, C.; Sutterlüty, H.; Grusch, M.; Grasl-Kraupp, B.; Berger, W.; Marian, B. Targeting fibroblast-growth-factor-receptordependent signaling for cancer therapy. Expert Opin. Ther. Targets 2011, 15, 829-846.

(42) Sharpe, R.; Pearson, A.; Herrera-abreu, M. T.; Johnson, D.; Welti, J. C.; Natrajan, R.; Reynolds, A. R.; Reis-filho, J. S.; Ashworth, A.; Turner, N. C.; et al. FGFR signaling promotes the growth of triple negative and basal-like breast cancer cell lines both in vitro and in vivo. Clin. Cancer Res. 2011, 17, 5275-5286.

(43) Koole, K.; Brunen, D.; van Kempen, P. M. W.; Noorlag, R.; de Bree, R.; Lieftink, C.; van Es, R. J. J.; Bernards, R.; Willems, S. M. FGFR1 Is a Potential Prognostic Biomarker and Therapeutic Target in Head and Neck Squamous Cell Carcinoma. Clin. Cancer Res. 2016, 22, 3884-3893.
(44) Haugsten, E. M.; Malecki, J.; Bjorklund, S. M. S.; Olsnes, S.; Wesche, J. Ubiquitination of Fibroblast Growth Factor Receptor 1 Is Required for Its Intracellular Sorting but Not for Its Endocytosis. Mol. Biol. Cell 2008, 19, 3390-3403.

(45) Doronina, S. O.; Toki, B. E.; Torgov, M. Y.; Mendelsohn, B. A.; Cerveny, C. G.; Chace, D. F.; DeBlanc, R. L.; Gearing, R. P.; Bovee, T. D.; Siegall, C. B.; Francisco, J. A.; Wahl, A. F.; Meyer, D. L.; Senter, P. D. Development of potent monoclonal antibody auristatin conjugates for cancer therapy. Nat. Biotechnol. 2003, 21, 778-784.

(46) Doronina, S.; Bovee, T.; et al. Novel Peptide Linkers for Highly Potent Antibody- Auristatin Conjugate. Bioconjugate Chem. 2008, 19, 1960-3.

(47) Hermanson, G. T. The Reactions of Bioconjugation. In Bioconjugate Techniques; Elsevier, 2013; pp 229-258.

(48) Lanciotti, J.; Song, A.; Doukas, J.; Sosnowski, B.; Pierce, G.; Gregory, R.; Wadsworth, S.; O’Riordan, C. Targeting adenoviral vectors using heterofunctional polyethylene glycol FGF2 conjugates. Mol. Ther. 2003, 8, 99-107.

(49) Thomas, T. P.; Shukla, R.; Kotlyar, A.; Kukowska-Latallo, J.; Baker, J. R. Dendrimer-based tumor cell targeting of fibroblast growth factor-1. Bioorg. Med. Chem. Lett. 2010, 20, 700-703.

(50) Cai, L.; Qiu, N.; Li, X.; Luo, K.; Chen, X.; Yang, L.; He, G.; Wei, Y.; Chen, L. A novel truncated basic fibroblast growth factor fragmentconjugated poly (ethylene glycol)-cholesterol amphiphilic polymeric drug delivery system for targeting to the FGFR-overexpressing tumor cells. Int. J. Pharm. 2011, 408, 173-182.

(51) Wiedlocha, A.; Madshus, I. H.; Mach, H.; Middaugh, C. R.; Olsnes, S. Tight folding of acidic fibroblast growth factor prevents its translocation to the cytosol with diphtheria toxin as vector. EMBO J. 1992, 11, 4835-4842.

(52) Lappi, D. A.; Matsunami, R.; Martineau, D.; Baird, A. Reducing the Heterogeneity of Chemically Conjugated Targeted Toxins: Homogeneous Basic FGF-Saporin. Anal. Biochem. 1993, 212, 446451.

(53) Tetzke, T. A.; Caton, M. C.; Maher, P. A.; Parandoosh, Z. Effect of fibroblast growth factor saporin mitotoxins on human bladder cell lines. Clin. Exp. Metastasis 1997, 15, 620-9.

(54) Guillemard, V.; Uri Saragovi, H. Prodrug chemotherapeutics bypass p-glycoprotein resistance and kill tumors in vivo with high efficacy and target-dependent selectivity. Oncogene 2004, 23, 36133621.

(55) de Goeij, B. E.; Vink, T.; Ten Napel, H.; Breij, E. C.; Satijn, D.; Wubbolts, R.; Miao, D.; Parren, P. W. Efficient payload delivery by a bispecific antibody-drug conjugate targeting HER2 and CD63. Mol. Cancer Ther. 2016, 15, 2688-2697.

(56) Hwang, W. Y. K.; Foote, J. Immunogenicity of engineered antibodies. Methods 2005, 36, 3-10.

(57) Sonvilla, G.; Allerstorfer, S.; Heinzle, C.; Stättner, S.; Karner, J.; Klimpfinger, M.; Wrba, F.; Fischer, H.; Gauglhofer, C.; SpieglKreinecker, S.; Grasl-Kraupp, B.; Holzmann, K.; Grusch, M.; Berger, W.; Marian, B. Fibroblast growth factor receptor 3-IIIc mediates colorectal cancer growth and migration. Br. J. Cancer 2010, 102, 1145-1156.

(58) Motoda, N.; Matsuda, Y.; Onda, M.; Ishiwata, T.; Uchida, E.; Naito, Z. Overexpression of fibroblast growth factor receptor 4 in highgrade pancreatic intraepithelial neoplasia and pancreatic ductal adenocarcinoma. Int. J. Oncol. 2011, 38, 133-43.

(59) Turkington, R. C.; Longley, D. B.; Allen, W. L.; Stevenson, L.; McLaughlin, K.; Dunne, P. D.; Blayney, J. K.; Salto-Tellez, M.; Van Schaeybroeck, S.; Johnston, P. G. Fibroblast growth factor receptor 4 (FGFR4): a targetable regulator of drug resistance in colorectal cancer. Cell Death Dis. 2014, 5, No. e1046.

(60) Zaid, T. M.; Yeung, T.-L.; Thompson, M. S.; Leung, C. S.; Harding, T.; Co, N.-N.; Schmandt, R. S.; Kwan, S.-Y.; RodriguezAguay, C.; Lopez-Berestein, G.; Sood, A. K.; Wong, K.-K.; Birrer, M. J.; Mok, S. C. Identification of FGFR4 as a Potential Therapeutic Target for Advanced-Stage, High-Grade Serous Ovarian Cancer. Clin. Cancer Res. 2013, 19, 809-820. 
(61) Wesche, J.; Haglund, K.; Haugsten, E. M. Fibroblast growth factors and their receptors in cancer. Biochem. J. 2011, 437, 199-213. (62) Sanz, J. M.; Giménez-Gallego, G. A partly folded state of acidic fibroblast growth factor at low pH. Eur. J. Biochem. 1997, 246, 328-35.

(63) Lambert, J. M. Drug-conjugated monoclonal antibodies for the treatment of cancer. Curr. Opin. Pharmacol. 2005, 5, 543-549.

(64) Wu, A. M.; Senter, P. D. Arming antibodies: prospects and challenges for immunoconjugates. Nat. Biotechnol. 2005, 23, 11371146.

(65) Hamblett, K. J.; Senter, P. D.; Chace, D. F.; Sun, M. M. C.; Lenox, J.; Cerveny, C. G.; Kissler, K. M.; Bernhardt, S. X.; Kopcha, A. K.; Zabinski, R. F.; Meyer, D. L.; Francisco, J. A. Effects of Drug Loading on the Antitumor Activity of a Monoclonal Antibody Drug Conjugate Effects of Drug Loading on the Antitumor Activity of a Monoclonal Antibody Drug Conjugate. Clin. Cancer Res. 2004, 10, $7063-7070$.

(66) Bryant, P.; Pabst, M.; Badescu, G.; Bird, M.; McDowell, W.; Jamieson, E.; Swierkosz, J.; Jurlewicz, K.; Tommasi, R.; Henseleit, K.; Sheng, X.; Camper, N.; Manin, A.; Kozakowska, K.; Peciak, K.; Laurine, E.; Grygorash, R.; Kyle, A.; Morris, D.; Parekh, V.; Abhilash, A.; Choi, J.; Edwards, J.; Frigerio, M.; Baker, M. P.; Godwin, A. In Vitro and In Vivo Evaluation of Cysteine Rebridged TrastuzumabMMAE Antibody Drug Conjugates with Defined Drug-to-Antibody Ratios. Mol. Pharm. 2015, 12, 1872-1879.

(67) Schindelin, J.; Arganda-Carreras, I.; Frise, E.; Kaynig, V.; Longair, M.; Pietzsch, T.; Preibisch, S.; Rueden, C.; Saalfeld, S.; Schmid, B.; Tinevez, J.-Y.; White, D. J.; Hartenstein, V.; Eliceiri, K.; Tomancak, P.; Cardona, A. Fiji: an open-source platform for biological-image analysis. Nat. Methods 2012, 9, 676-682. 